\title{
Jak jazyky vymírají nebo ztrácejí na životnosti a do jaké míry je možné je udržet při životě
}

\author{
ZDENĚK SALZMANN*
}

How Languages Die or Lose their Viability, and to What Extent they Can Be Maintained

\begin{abstract}
The article begins by giving the reasons why the number of languages spoken in the world today cannot be ascertained with any precision. It then continues with a survey of the viability of contemporary North American Indian languages. The reasons for the very rapid rate of language death are discussed next, with focus on North American Southwest culture area. The article concludes with some practical pointers for the revitalization of threatened languages.
\end{abstract}

Keywords: number of languages, language death, North American Indian languages, languages of the Southwest, language revitalization

Kolik je dnes na světě jazyků?

Většina současných lingvistů a kulturních antropologů by se shodla, že existuje asi šest až sedm tisíc jazyků. Je několik důvodů, proč je toto číslo tak nepřesné. Za prvé hranice mezi pojmy jazyka a nářečí nelze vždy dobře stanovit. Vzájemně srozumitelné podoby jazyka se sice považují za nářečí, s tímto kritériem jsou však spojeny určité problémy. V kolika procentech srozumitelnost začíná a kde končí? A pak je nutno přihlédnout k historickým, politickým a sociokulturním faktorům daného př́padu. Tak například čeština je vzájemně srozumitelná se slovenštinou, ale považují se za dva jazyky, které mají své vlastní jazykové normy, a existuje celá řada česko-slovenských a slovensko-českých slovníků. Pokud by někdo tvrdil, že slovenština je nářečím češtiny, Slováci by se oprávněně cítili dotčeni a kulturně podceněni.

Druhý důvod je prostě ten, že naše kulturněantropologické informace o několika územích na světě jsou stále ještě neúplné - například o vnitrozemí Brazílie v povodí řek Negro a Amazonky a o Nové Guineji. Je velmi pravděpodobné, že stále existují jazyky, o nichž dosud nevíme nic anebo jen velmi málo. Třetí a nejzávažnější důvod je ten, že se celkový počet jazyků na světě stále a rychle zmenšuje.

\section{Indiánské jazyky Severní Ameriky}

V Severní Americe na sever od vyspělých kultur středního Mexika se před pěti stoletími mluvilo zhruba 400 až 500 různými indiánskými jazyky patřícími k mnoha jazykovým rodinám. Přesněji se počet těchto jazyků nedá určit, protože spolehlivé informace pro rané období severoamerické kolonizace Evropany neexistují. Podle mých odhadů je kolem 190 indiánských jazyků stále živých a přes 100 jazyků vymřelo během posledních dvou století. Kolik jich vymřelo předtím, než máme spolehlivá data, nelze ani odhadnout. I když se stále ještě mluví téměř 200 severoamerickými indiánskými jazyky, není

Prof. Zdeněk Salzmann, 120 Highland Drive South, 86351-9538 Sedona, Arizona, United States of America. E-mail: dennysalz@aol.com 
toto zjištění zdaleka tak potěšitelné, jak by se na první pohled mohlo zdát. Z těchto 200 jazyků mluví přibližně 65 jazyky už jen velmi málo nejstarších členů indiánských kmenů, což ovšem znamená, že s velkou pravděpodobností většina těchto jazyků během deseti až dvaceti let zanikne. Zhruba 85 jazyky mluví dnes pouze dospělí členové některých kmenů, v žádném případě ne však všichni, ale téměř žádné děti. Kromě dospělých členů kmenů mluví dnes i značný počet jejich dětí jen 45 jazyky, i když všichni tito indiáni jsou téměř bez výjimky dvojjazyční. K těmto kmenům patří hlavně jazyky na severu severoamerického kontinentu (např́klad eskymácko-aleutské jazyky), jazyky ve střední a východní Kanadě, v Mexiku a v kulturní oblasti Jihozápadu, např́íklad hopijština (Hopi), navažština (Navajo) a zunijština (Zuni). ${ }^{1}$ Některé indiánské kmeny se sice v posledních letech pokoušejí úpadek svých jazyků zastavit nebo zpomalit a zahájily programy jazykové revitalizace nebo alespoň jazykového udržování a posilování. Ztráta jejich jazyků ve prospěch angličtiny, případně španělštiny či portugalštiny, je ale bohužel neodvratná a ve většině př́ipadů se stále urychluje. V některých základních školách v indiánských rezervacích se začalo vyučovat místním indiánským jazykům několik hodin týdně, ale mateřský (rodný) jazyk je řeč, kterou mluví matka ke svému dítěti od narození, a to je dnes už téměř výjimka spíše než pravidlo. Jestliže matky v kmenových rodinách mluví ke svým dětem anglicky - jak tomu v mnoha př́padech je - pak se už jejich rodné jazyky nemohou udržet. Jedna mladá navažská studentka problém ztráty jazyka velmi výstižně charakterizovala v anglickém jazyce: „Mohla bych se zaručit, že by moje děti mluvily plynně navažsky jenom $v$ tom případě, když by byly ochotny žít v hoganu (tradičním navažském obydlí) a každý den nosit domů vodu v kýblu alespoň míli.“

\section{Proč jazyky zanikají}

Podle Davida Crystala, jednoho z nejlepších současných lingvistů, každý měsíc během tohoto století vymírají a budou vymírat v průměru dva jazyky a četnost jejich zániku se bude spíše zvyšovat než snižovat [Crystal 2000]. To je téměř neuvěřitelná statistika, ale Crystalovo tvrzení je založeno na velmi pečlivém výzkumu.

Proč jazyky dnes tak rychle vymírají? Vypůjčíme-li si z jaderné fyziky pojem kritického množství, zjistíme, že zhruba 1500 jazyků má dnes méně než 1000 plynně mluvících osob. Kdyby tyto malé (vesnické, kmenové) společnosti byly víceméně izolovány, jejich jazyky by se sice časem měnily, ale zachovávaly. Je ale nutné si uvědomit, že většina těchto malých společností žije například v zemích, kde běžným jazykem je angličtina nebo francouzština (Kanada), angličtina (Spojené státy), španělština (Mexiko), nebo portugalština (Brazílie). Aby se těmto malým společnostem podařilo udržet, musí se umět dohovořit národním nebo úředním jazykem toho kterého státu. Protože je rodný jazyk společnosti nejbytostnějším znakem její etnické totožnosti, ztrátu rodného jazyka lze považovat za počátek etnického zobecnění jejích členů.

Když se hovoří o stavu životnosti jazyků světa, je na místě rozlišovat několik jejich stupňů: bezpečný, životaschopný, potenciálně ohrožený, ohrožený, vážně ohrožený, vymírající a mrtvý. Nebezpečí zániku začíná ve stupni potenciální ohroženosti, protože tam jde o jazyky společností, které jsou sociálně a ekonomicky natolik znevýhodněné tlakem velkých společností, jež je obklopují, že začínají ztrácet mluvčí mezi svými dětmi.

1 Při počeštování jmen indiánských kmenů a jazyků se držím zásad svého článku [Salzmann 1972]. 
Proč velmi malé národy (vesnické či kmenové) a jejich jazyky tak rychle vymírají? Důvodů bylo a je mnoho, např́íklad rychlý vzrůst politické moci velkého okolního státu; př́rodní katastrofy jako zemětřesení, povodeň, hurikán; dezertifikace, tedy rozšiřování pouště vyčerpáním půdy nadměrným obděláváním nebo spásáním; zhoubné nemoci; hladomor; velká sucha; nucená migrace $z$ vesnic do měst; etnické nebo náboženské rozpory končící válkou; negativní postoj k místnímu rodnému jazyku; a tzv. folklorizace jazyka, tj. užívání místního jazyka jen pro zcela nezávažné účely.

Potud obecné úvodní poznámky. Protože by bylo těžké hovořit konkrétně o jazycích celého světa nebo alespoň celého kontinentu, soustředím se ted’ na kulturní oblast severoamerického Jihozápadu. Mám proto dobrý důvod: žil jsem v této oblasti v letech 1956 až 1966 a žiji tu znovu od roku 1989, celkem tedy už třicet let.

\section{Indiánské jazyky severoamerického Jihozápadu}

Severoamerickou kulturní oblast Jihozápad lze vymezit zcela přesně ve Spojených státech, méně přesně v Mexiku. Ve Spojených státech jsou jádrem této oblasti státy Arizona a Nové Mexiko, a patří k ní také nejzápadnější a nejjižnější části Texasu, jihozápadní roh Colorada, jižní cíp Nevady a velmi malá část Utahu na jih od řeky San Juan. Většina antropologů považuje hranice této kulturní oblasti v Mexiku na jih od obratníku Raka, ale některé východní části tohoto území jsou stále ještě nedostatečně prozkoumány a jazykově zařazeny. Proto se v tomto krátkém článku omezím jen na kulturní oblast Jihozápadu ve Spojených státech (srv. Schematickou mapku č. 1, vymezující kulturní oblast Jihozápadu, v Př́loze textu).

Jihozápad je domovem mnoha indiánských národů, jimž se až do dnešních dnů podařilo zachovat tradiční kultury do větší míry než kdekoliv jinde ve Spojených státech. A stalo se tak, i když mnoho těchto indiánských národů přišlo do styku s Evropany poprvé už v letech 1540 až 1542, kdy Francisco Vásquez de Coronado vedl velkou výzkumnou výpravu z nynějšího Mexika na sever.

Na rozdíl od jiných kulturních oblastí Severní Ameriky, indiánské národy Jihozápadu se dělí na dvě výrazně odlišné skupiny - Pueblany, kteří už po staletí žijí v pueblech (vesnicích), a Nepueblany, tj. ostatní indiánská etnika. Téměř všechny tyto indiánské národy byly podněcovány úspěchy středoamerických civilizací na jih od nich (například zemědělstvím a hrnčířstvím) a sloučily pak různé kulturní vlivy zvenčí svým vlastním způsobem. Následkem toho je Jihozápad kulturně velmi pestrá oblast, známá dnešním Američanům zejména svými vkusnými rukodělnými výrobky a krásnými uměleckými předměty. Na Jihozápadu se stále ještě mluví indiánskými jazyky, které patří dokonce k šesti jazykovým rodinám - kereské (Keresan), kajovsko-tanoské (Kiowa-Tanoan), nadenejské (Na-Dene), kočimi-jumské (Cochimi-Yuman), jutoaztécké (Uto-Aztecan) a jednočlenné jazykové rodině - zunijštině (Zuni). ${ }^{2}$ Protože je toto jazykové území velmi bohaté a rozrůzněné, připojuji tabulku jeho jazyků a schematickou mapku jejich rozmístění v kulturní oblasti (k teritoriálnímu rozložení jazyků a dialektů severoamerického Jihozápadu [Driver a Massey 1957]; viz Tabulka č. 1 a Schematická mapka č. 2 v Př́loze textu).

2 Roztřídění jazykových rodin Jihozápadu a jejich dělení na větve, podvětve, jazyky a dialekty se řídí prací [Goddard 1996]. 
Počet obyvatel velké většiny indiánských národů na Jihozápadu je velmi malý. ${ }^{3}$ Přibližná čísla pro jednotlivá puebla se pohybují mezi 300 a 9 tisíc lidmi s průměrem okolo 1500 obyvatel. Nepueblané jsou početnější. Navahů je dnes kolem 300 tisíc a národy Pima, Tohono O’odham a všechny kmeny Apačů mají populace v rozmezí 12 až 25 tisíc členů. Velikost kmenů Havasupai, Walapai a Yavapai se pochybuje jen mezi 600 a 2 tisíci příslušníky. Lze tedy říci, že ve většině případů není kritické množství mluvčích těchto různých národů dostatečně velké, aby jejich jazyky dlouhodobě přežily.

Níže uvedené informace se nedaly zjistit ve všech př́padech zcela přesně a situace se bez pochyby stále zhoršuje. Přesto jsou uvedená data zajímavá a počet jazyků v mnoha ostatních kulturních oblastech Severní Ameriky se stále zmenšuje.

V kulturní oblasti Jihozápad mluví následujícími jazyky (dialekty) stále poměrně hodně dětí, a jsou proto životaschopné po několik dalších generací: ${ }^{4}$ Cochiti, Havasupai, Hopi, Jemez, Navajo, Pima, San Felipe, Santa Ana, Santo Domingo, Taos, Tohono O'odham (Papago), Walapai, Yavapai, Yaqui, Zia, Zuni a západoapačské dialekty.

K jazykům nebo dialektům, kterými mluví už jen dospělí, ale nemluví žádné nebo jen velmi málo dětí, a proto s velkou pravděpodobností zaniknou během dvou nebo tří generací, patří Acoma, Chiricahua, dialekty jazyka Cocopa, Isleta, Jicarilla, Laguna, dialekty jazyka Maricopa, Mescalero, Mohave, Nambe, Picuris, Pojoaque, Quechan, Sandia, San Ildefonso, San Juan, Santa Clara a Tesuque. Jazyky Lipan a Piro už nikdo nemluví.

\section{Poznámky o prehistorii a historii indiánských jazyků Jihozápadu a jejich mluvčích}

Věnujme se nejprve národům Jihozápadu obecně. Pueblané této oblasti žili ve vesnicích (pueblech) už mnoho staletí. Jsou potomky prehistorických Anasazijců (Anasazi) a Mogolonců (Mogollon), jejichž kultury se vyznačovaly pěstováním kukuřice, fazolí a dýní, výrobou košíků a hliněných nádob a komplexními náboženskými obřady. Oblast Pueblanů byla obklopena přibližně deseti jinými společnostmi. Podle své jazykové příslušnosti se tyto národy dělí na Navahy a Apače, dále jumsky mluvící kmeny podél řek Colorado a Gila, konečně pak jižní Jutoaztéky.

Navahové. Předkové dnešních Navahů a jim př́ibuzných Apačů přišli na Jihozápad ze severozápadní Kanady. Tam dodnes žijí kmeny mluvící jazyky athabaské jazykové rodiny, a od nich se Navahové kdysi oddělili. Dobu jejich příchodu na Jihozápad nelze přesně stanovit, ale $s$ velkou pravděpodobností to bylo někdy během 15 . století. Navažská rezervace, zřízená v roce 1868, byla během doby několikrát rozšířena (zejména v Arizoně). Dnes má rozlohu přes 15 milionů akrů ${ }^{5}$ a je tedy mnohem větší než stát Massachusetts. Navažštinou se stále ještě mluví a jsou dokonce i staří členové navažského národa, kteří jsou dodnes monolingvní.

Apačové. Nedlouho po tom, kdy Apačové dospěli na Jihozápad, rozpadli se na několik nezávislých skupin, které si během doby vytvořily své vlastní jazyky (popřípadě dialekty). Dnes žijí Apačové v několika rezervacích v Arizoně a Novém Mexiku a také jim se podařilo rozlohu jejich rezervací zvětšit. Co se týká jejich jazyků (dialektů), jen

3 Data týkající se indiánských národů (kmenů) kulturní oblasti Jihozápad pochází ze souborné práce [Salzmann-Salzmann 1997].

4 Výčet jmen jazyků či dialektů je uveden v obvyklé anglické podobě, tj. s velkým počátečním písmenem.

5 Akr, angosaská plošná jednotka, odpovídá rozloze 40,5 arů, tj. více než 4 tisíců metrů čtverečních. 
u Západních Apačů (Western Apache) mluví ještě značný počet dětí apačsky (ovšem vedle angličtiny).

Jakijci. Tradiční domov Jakijců byl po obou březích řeky Yaqui, která se vlévá do Kalifornského zálivu v mexickém státu Sonora. Po větší část 19. století se Jakijci ubránili osídlování své úrodné půdy Mexičany, ale ke konci toho století byla jejich kmenová půda obsazena mexickým vojskem. Když se jim Jakijci nepodrobili, kolem pěti tisíců jich bylo prodáno do otroctví plantážníkům v mexických státech Oaxaca a Yucatan za 60 pesos za osobu. Aby se vyhnuli podobnému osudu, někteří Jakijci utekli na sever do Spojených států. Kupodivu byli s to všechny pohromy, které jejich národ stihly, přežít. Před 40 lety existovalo 21 jakijských komunit a z nich plných 18 představovalo soběstačná střediska jejich tradičního života. Dnes jich žije v několika obcích jižně od Phoenixu a ve vesnici Pascua v okolí Tucsonu v Arizoně okolo šesti tisíc a také některé jejich děti stále ještě dovedou mluvit jakijsky.

Prehistoričtí Jutoaztékové. Podle nedávné a spolehlivé hypotézy žili mluvčí prajutoaztéčtiny pravděpodobně ve Střední Americe někdy před 5500 až 4500 lety, a potom se rozšśríili směrem na sever do svých nynějších domovů. ${ }^{6}$

\section{Revitalizace indiánských jazyků v praxi}

Nakonec připojuji ještě několik praktických poznámek z mé vlastní zkušenosti. V roce 1979 jsem začal na žádost kmenové rady Arapahů ve Wyomingu (kulturní oblast Velkých plání) organizovat posilování a revitalizaci jejich jazyka, arapažštiny. Myšlenka zachránit ohrožený jazyk malé společnosti před předčasným zánikem je často inspirována lingvistickým antropologem, který v dané lokalitě dělá terénní výzkum. Tomu pak může být svěřen i úkol, aby záchranný program zorganizoval. Proti všemu očekávání nemusí část dané společnosti s takovými plány plně souhlasit. Zvláště v dnešní době mají mladí členové malé společnosti mnohem větší užitek z dobré znalosti např́́klad angličtiny než ze snahy zvládnout rodný jazyk, kterým mluví jenom tisíc nebo 2 tisíce lidí, na úkor jazyka společnosti, jež je obklopuje a na které budou patrně mnozí jednotlivci ekonomicky záviset. Proto musí lingvistický antropolog postupovat rozvážně. Je mimo jiné důležité, aby se obeznámil se členy kmenové rady nebo podobné instituce a její politikou, poslouchal starší členy kmene spíše než aby příliš veřejně záchranou akci sám plánoval a nechal povolané členy společnosti formulovat, jakými metodami by se nejlépe dosáhlo daného cíle. Přitom se ale musí lingvistický antropolog obratně snažit, aby plánovaný projekt zůstal ve zvládnutelných a praktických mezích. Navíc je nutno myslet hodně dopředu, protože revitalizace jazyka je dlouhodobá záležitost a s největší pravděpodobností osoba, která revitalizaci navrhla a pomohla organizovat, nepřežije její dokončení.

Shrňme nynější arapažský jazykový stav. Jazyková situace u Severních Arapahů je kritická, avšak u Jižních Arapahů v Oklahomě je ještě horší. Až na nepatrné výjimky jsou jednotlivci, kteří ještě mluví arapažsky plynně (i když arapažštinu už běžně vůbec neužívají), jen členové nejstarší generace. Rodiče už arapažsky doma na děti nemluví, protože sami tento jazyk neovládají. Existuje pouze malý počet jednotlivců s aktivní znalostí arapažštiny a také ten se velmi rychle zmenšuje. Převážná většina Arapahů je prakticky vzato monolingvní, a proto se dnes dává přednost angličtině ve všech situacích,

$6 \quad$ Hypotézu týkající se pradomova Jutoaztéků formulovala [Hill 2001]. 
včetně tradičních obřadních příležitostí jako je např́íklad tanec slunce. Arapažština ztrácí životaschopnost, tj. schopnost úspěšně se přizpůsobit novým komunikačním situacím.

Příliš nepomůže, že jsem s pomocí arapažských seniorů nahrál přes čtyřicet videolekcí pro žáky základních škol arapažské rezervace. Mateřskému jazyku se děti nenaučí až teprve ve škole, nebot se musí jej učit od matek od nejranějšího dětství. Rovněž Arapahům nebude př́liš platný ani slovník současné arapažštiny (Dictionary of Contemporary Arapaho Usage), který jsem pro ně v roce 1983 zpracoval [Salzmann 1983].

Jsou ale i obecnější aspekty revitalizace jazyků, ke kterým je nutno přihlédnout. K životnosti ohroženého jazyka např́klad přispívá, když se podaří nějakým způsobem zvýšit prestiž jeho mluvčích nebo území, kde žijí. Toho se dosáhne, když je takový jazyk alespoň symbolicky zapojen do školního programu vyšší územní správní jednotky a když se někteří mluvčí ohroženého jazyka stanou učiteli a učitelkami na základních školách. Ohroženému jazyku může i nepřímo napomáhat, jestliže se na jeho území nacházejí některé suroviny (například ropa), které mají význam pro hospodářství společnosti, jež mluvčí ohroženého jazyka obklopuje. Důležitost těchto a jiných faktorů se ovšem může lišit od jedné situace $\mathrm{k}$ druhé. $\mathrm{V}$ každém př́ípadě však pomáhá, podaří-li se pozvednout životní úroveň malé společnosti v poměru ke společnosti dominantní.

Zajímavý př́iklad složitosti kulturních a jazykových adaptací tradiční kultury ke kultuře dominantní společnosti nám poskytuje kmen Walapai v Arizoně. Před dvaceti lety členů tohoto kmene, kteří stále ještě dovedli plynně mluvit (ovšem vedle angličtiny) svou rodnou řečí walapai, bylo kolem 1 500. Zato ale jen 50 \% jejich dětí do věku 13 let se dovedlo jazykem walapai domluvit. Ztráta jazykové kompetence byla způsobena těmi rodiči, kteří se rozhodli nemluvit doma rodným jazykem, aby jejich děti ve veřejných školách nemusely podstupovat ponížení proto, že mluví podle nich nedůstojným jazykem lépe než angličtinou. A uvedme ještě jeden př́klad jiného druhu. V mnoha navažských rodinách je navažština z velké míry omezena na běžná každodenní témata mezi členy rodiny a přáteli a na náboženskou a rituální oblast jejich společnosti, protože se abstraktní pojmy tohoto žánru nedají adekvátně přeložit do angličtiny. Angličtina se užívá ve styku s Američany, pro obchodní a administrativní záležitosti a pro korespondenci. Vytvořil se tu tedy jakýsi vzájemně se doplňující bilingvizmus.

Nyní si ale uvědomuji, že se začínáme pohybovat v bludném kruhu, protože úspěchy jednotlivců v malých ohrožených společnostech jsou zpravidla na úkor snah udržet si nejcharakteričtější rysy tradiční kultury a mateřský jazyk. Jsou tu ještě další zajímavé otázky, například do jaké míry se má s revitalizací jazyka revitalizovat i tradiční kultura, ale snad bude nejlépe, když si necháme nějaké problémy napříště. 


\section{Literatura}

Crystal, David. [2000]. Language Death. Cambridge: Cambridge University Press.

Driver, Harold E. - Massey, William C. [1957]. Comparative studies of North American Indians. (In: Transactions of the American Philosophical Society. New series, Vol. 47, Part 2). Philadelphia: The American Philosophical Society.

Goddard, Ives. [1996]. Introduction. In. Languages. Vol. 17. Handbook of North American Indians. Washington: Smithsonian Institution, s. 1-16.

Hill, Jane H. [2001]. Proto-Uto-Aztecan: A community of cultivators in central Mexico? American Anthropologist 103 (December 2001), No. 4 (New Series), s. 913-934.

Salzmann, Zdeněk. [1972]. Př́spěvek k vytvoření českých podob indiánských jmen. Naše řeč 55 (1972), číslo 5, s. 250-262.

Salzmann, Zdeněk. [1983]. Dictionary of Contemporary Arapaho Usage. (Arapaho Language and Culture Instructional Materials Series, No. 4. General editor: William J. C’Hair). Wind River Reservation (Wyoming).

Salzmann, Zdeněk - Salzmann, Joy M. [1997]. Native Americans of the Southwest: The serious traveler's introduction to peoples and places. Boulder: Westview Press.

Zdeněk Salzmann (*1925) má absolutorium z Karlovy univerzity (1948) a doktorát z Indiana University (1963). V letech 1968-1989 byl profesor na University of Massachusetts $v$ Amherstu a $v$ di̊chodu působil do roku 2009 jako profesor na částečný úvazek na Northern Arizona University ve Flagstaffu. Pracoval jako hostujicí profesor na několika univerzitách ve Spojených státech a v Evropě. Je autorem kolem 400 publikací včetně několika amerických univerzitních učebnic. Mezi hlavní témata jeho univerzitních prednášek náležela lingvistická a kulturní antropologie a jazyky, kultury a ústní slovesnost severoamerických indiánů. 


\section{Př́lohy}

Schematická mapka č. 1: Vymezení kulturní oblasti Jihozápadu na schematické mapě Severní a Střední Ameriky (kulturní oblast Jihozápadu je označena zkratkou JZ).

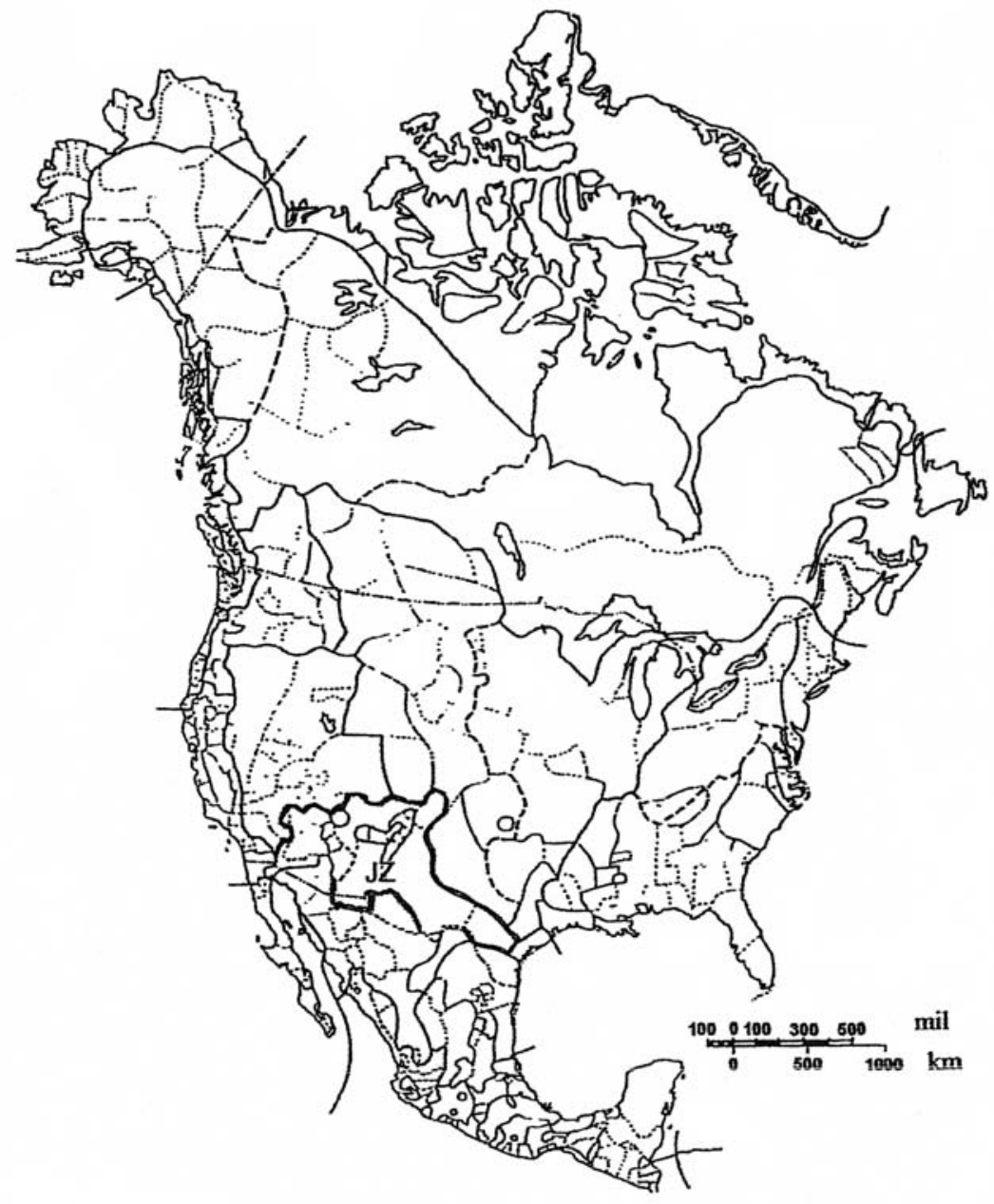


Schematická mapka č. 2: Umístění jazyků a dialektů severoamerického Jihozápadu.

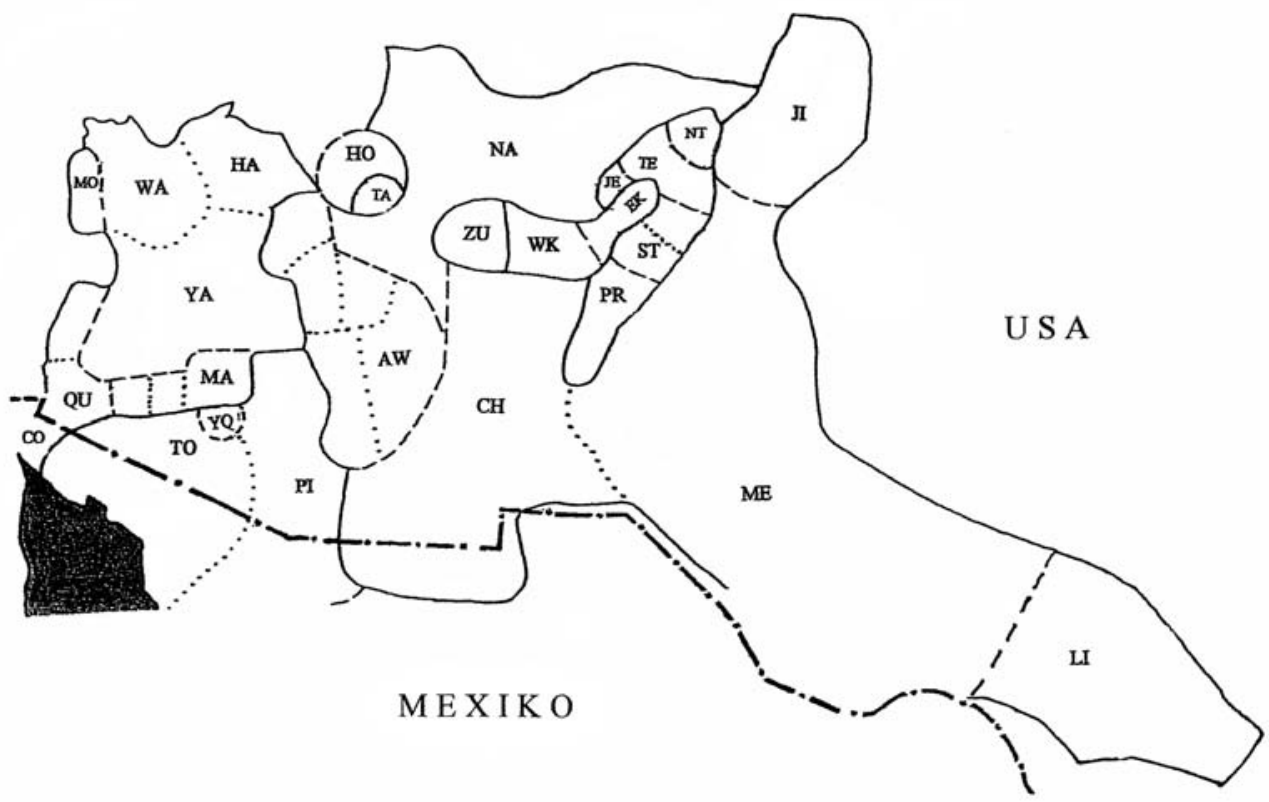

Na mapě jsou vyznačena území jazyků a dialektů této kulturní oblasti. Jazyky jsou uvedeny $\mathrm{v}$ anglické podobě pod těmito zkratkami:

$\begin{array}{lll}\text { AW dialekty Western Apachean } & \text { NT } & \text { jazyky Northern Tiwa (Taos a Picuris) } \\ \text { CH } & \text { Chiricahua } & \text { PI Pima } \\ \text { CO dialekty jazyka Cocopa } & \text { PR Piro } \\ \text { EK dialekty Eastern Keresan } & \text { QU Quechan } \\ \text { HA Havasupai } & \text { ST dialekty Southern Tiwa } \\ \text { HO Hopi } & \text { TA Tano (Hopi Tewa neboli Arizona Tewa) } \\ \text { JE dialekty jazyka Jemez } & \text { TE dialekty Tewa v Novém Mexiku } \\ \text { JI Jicarilla } & \text { TO Tohono O’odham (Papago) } \\ \text { LI Lipan } & \text { WA Walapai } \\ \text { MA dialekty jazyka Maricopa } & \text { WK dialekty Western Keresan } \\ \text { ME Mescalero } & \text { YA Yavapai } \\ \text { MO Mohave } & \text { YQ Yaqui } \\ \text { NA Navajo } & \text { ZU Zuni }\end{array}$

Zdroj: přizpůsobeno z Driver, Harold E. - Massey, William C. [1957]. Comparative studies of North American Indians. (In: Transactions of the American Philosophical Society. New series, Vol. 47, Part 2). Philadelphia: The American Philosophical Society.

Pozn.: Tato mapa představuje pouze schéma. Území malých etnických skupin jsou zvětšená, vzájemně se překrývající kmenová (jazyková) území nejsou vyznačena. Během času se posunující hranice mezi nimi John nevzal v úvahu. 
Tabulka č. 1: Indiánské jazyky kulturní oblasti Jihozápad ve Spojených státech

\begin{tabular}{|c|c|c|c|}
\hline Jazykové rodiny & Větve & Podvětve & $\begin{array}{l}\text { Jazyky, popř́padě puebla (dialekty } \\
\text { jsou naznačeny spojovníkem) }\end{array}$ \\
\hline Keresan & $\begin{array}{l}\text { Western Keresan } \\
\text { Eastern Keresan } \\
\text { (Rio Grande Keresan) }\end{array}$ & & $\begin{array}{l}\text { Acoma-Laguna } \\
\text { Zia-Cochiti-Santo Domingo-Santa } \\
\text { Ana-San Felipe }\end{array}$ \\
\hline Kiowa-Tanoan & $\begin{array}{l}\text { Jemez } \\
\text { Piro } \\
\text { Tiwa } \\
\text { Tewa }\end{array}$ & $\begin{array}{l}\text { Northern Tiwa } \\
\text { Southern Tiwa }\end{array}$ & $\begin{array}{l}\text { Jemez-Pecos } \\
\text { Piro } \\
\text { Taos } \\
\text { Picuris } \\
\text { Isleta-Sandia } \\
\text { San Juan-Santa Clara-San } \\
\text { Ildefonso-Pojoaque-Nambe-Tesuque } \\
\text { Tano (Arizona Tewa, Hopi Tewa) }\end{array}$ \\
\hline Na-Dene & Apachean & $\begin{array}{l}\text { Western } \\
\text { Eastern }\end{array}$ & $\begin{array}{l}\text { Navajo } \\
\text { Western Apache (Tonto-Cibecue- } \\
\text { San Carlos-White Mountain) } \\
\text { Mescalero-Chiricahua } \\
\text { Jicarilla } \\
\text { Lipan }\end{array}$ \\
\hline Cochimí-Yuman & Yuman & $\begin{array}{l}\text { Pai } \\
\text { River } \\
\text { Delta-California }\end{array}$ & $\begin{array}{l}\text { Upland Yuman: dialekty } \\
\text { Havasupai-Walapai-Yavapai } \\
\text { Mohave } \\
\text { Quechan (Yuma) } \\
\text { dialekty jazyka Maricopa } \\
\text { dialekty jazyka Cocopa }\end{array}$ \\
\hline Uto-Aztecan & $\begin{array}{l}\text { Hopi } \\
\text { Tepiman } \\
\text { Taracahitan } \\
\end{array}$ & Upper Piman & $\begin{array}{l}\text { Hopi } \\
\text { Pima-Tohono O’odham (Papago) } \\
\text { Yaqui - dialekt jazyka Cahitan }\end{array}$ \\
\hline Zuni & & & Zuni \\
\hline
\end{tabular}

Pozn.: Pouze jazyky kulturní oblasti Jihozápad ve Spojených státech jsou v této tabulce zahrnuty a uvedeny v anglických podobách. Jazyky vytištěné kurzivou jsou dnes už vymřelé. Všechna jména indiánských kmenů a jazyků se vyskytují v několika synonymních nebo pravopisných variantách. Podoby užité v této tabulce jsou nejběžnější.

Zdroj: přizpůsobeno z Driver, Harold E. - Massey, William C. [1957]. Comparative studies of North American Indians. (In: Transactions of the American Philosophical Society. New series, Vol. 47, Part 2). Philadelphia: The American Philosophical Society. 